\title{
Effect of 17\% EDTA on removal of canal wall smear layer and calcium hydroxide dressing: part II
}

\author{
Efetividade do EDTA 17\% na remoção da smear layer e da medicação intracanal de hidróxido de cálcio das paredes \\ dos canais radiculares: parte II
}

Rosana de Souza PEREIRA ${ }^{1}$

Gisela de Souza PEREIRA'

Juliana Machado BARROSO'

Carlos Henrique Siqueira BARROS²

Márcia Gabriella Lino de Barros BORTOLOTTI ${ }^{3}$

José Luiz Cintra JUNQUEIRA ${ }^{3}$

\section{ABSTRACT}

\section{Objective}

the aim of this study was to evaluate, by scanning electron microscopy, the effectiveness of 17\% EDTA on removal of canal wall smear layer and calcium hydroxide dressing in different thirds of root canal.

\section{Methods}

Ttwenty-four premolars were instrumented in the cervical and middle thirds using Gates-Glidden drills. At the working length, the canal was widened up to \# 35 file, followed by scaling up to file \# 50. After instrumentation, the teeth were divided into four groups according to the treatment received: Gl - irrigation performed with $5 \mathrm{ml}$ of $\mathrm{NaOCl} 2.5 \%$; Gll - irrigation with $5 \mathrm{ml}$ of 17\% EDTA for 2 and a half minutes, submitted to agitation with file \# 15, followed by irrigation with $5 \mathrm{ml}$ of 2.5\% NaOCl; GIII - irrigation with $5 \mathrm{ml}$ of NaOCl 2.5\%, drying, application of temporary dressing of Ca $(\mathrm{OH})_{2}$ with propylene glycol and sealing. After 5 days, removing the sealing irrigation with $5 \mathrm{ml}$ of $17 \%$ EDTA for 2 and a half minutes, submitted to agitation with file \# 15, followed by a final flush with $5 \mathrm{ml}$ of 2.5\% NaOCl; GIV-irrigation with $5 \mathrm{ml}$ of $17 \%$ EDTA for 2 and a half minutes, submitted to agitation with file \# 15 , followed by irrigation with $5 \mathrm{ml}$ of $2.5 \% \mathrm{NaOCl}$, drying and after use of the medication in $\mathrm{Ca}(\mathrm{OH})$, with the sealing and propylene glycol which was removed after 5 days performing the irrigation with $5 \mathrm{ml}$ of $17 \%$ EDTA for 2 and a half minutes, submitted to agitation with file \# 15, followed by using $5 \mathrm{ml} 2.5 \% \mathrm{NaOCl}$. Next, the teeth were prepared and taken to the scanning electron microscope .

\section{Results}

The images revealed: Group I - a marked presence of smear layer in all three thirds, Group II - removal of almost all of the smear layer in the cervical third and removal of large quantity in the middle third, whereas in the apical third a large quantity of smear layer still remained however, in comparison with the other groups, this was shown to be cleaner; Group III - in the three thirds, the presence of smear layer was observed, which was shown to be much less compacted than that observed in Group 1; Group IV-in all the thirds there was reduction of smear layer and $\mathrm{Ca}(\mathrm{OH})_{2}-\mathrm{based}$ medication, and presence of several unobstructed dentinal tubules could be observed, demonstrating the second best result observed.

Conclusion

It could be concluded that the use of $17 \%$ EDTA favored removal of the smear layer and intracanal medication residues in all thirds of the root canal.

Indexing terms: Calcium hydroxide. Dental pulp cavity. Edetic acid. Smear layer.

\section{RESUMO}

\section{Objetivo}

Avaliar através de Microscopia Eletrônica de Varredura, a eficácia do EDTA a 17\% na remoção da smear layer e da medicação de hidróxido de cálcio nos diferentes terços do canal radicular.

\section{Métodos}

Vinte e quatro pré-molares foram instrumentados nos terços cervical e médio utilizando-se brocas Gates-Glidden. No comprimento de trabalho realizou-se o alargamento até a lima \#35 seguido do escalonamento até a lima \#50. Após, os dentes foram divididos em quatro grupos de acordo com o tratamento recebido: Gl - irrigação realizada com $5 \mathrm{ml}$ de hipoclorito de sódio a 2,5\%; Gll - irrigação com $5 \mathrm{ml}$ de EDTA $17 \%$, durante 2 minutos e meio, submetidos a agitação com a lima \#15, seguidos de uma irrigação com $5 \mathrm{ml}$ de NaOCl a 2,5\%; GIII - irrigação com 5 ml de hipoclorito de sódio a 2,5\%, secagem, aplicação de medicação intracanal de $\mathrm{Ca}(\mathrm{OH})$ associado ao propilenoglicol e selamento, após 5 dias, remoção do selamento, irrigação com $5 \mathrm{ml}$ de EDTA 17\%, durante 2 minutos e meio, submetidos a agitação com a lima \#15, seguida de irrigação final com 5 ml de $\mathrm{NaOCl}$ a 2,5\%; GIV - irrigação com $5 \mathrm{ml}$ de EDTA 17\%, durante 2 minutos e meio, submetídos a agitação com a lima \#15, seguidos de uma irrigação com 5 ml de $\mathrm{NaOCl}$ a 2,5\%, secagem e após o uso da medicação intracanal de $\mathrm{Ca}(\mathrm{OH})$, associado ao propilenoglicol e selamento que foi removido após 5 dias realizando-se a irrigação com $5 \mathrm{ml}$ de EDTA 17\%, durante 2 minutos e meio, submetidos a agitação com a lima \#15, seguida da utilização de 5 ml de $\mathrm{NaOCl}$ a 2,5\%. A seguir, os dentes foram preparados e levados ao microscópio eletrônico de varredura.

\section{Resultados}

As imagens revelaram: grupo I - presença marcante de smear layer nos três terços; grupo II - nota-se a menor quantidade de smear layer no terço cervical e médio enquanto no apical há presença mais marcante; grupo III- no terço cervical e apical há presença de smear layer compactada nas paredes do canal e o aspecto mais disperso da medicação enquanto no terço médio nota-se presença da medicação no interior dos canalículos; grupo IV- em todos os terços houve redução da smear layer e da medicação e a presença de vários canalículos dentinários desobstruídos.

\section{Conclusão}

Pode-se concluir que o uso do EDTA a 17\% favoreceu a remoção da lama dentinária e dos resíduos da medicação intracanal em todos os terços do canal radicular.

Termos de indexação: Hidróxido de cálcio. Cavidade pulpar. Ácido edético. Camada de esfregaço.

\footnotetext{
${ }^{1}$ Universidade Federal do Espírito Santo, Faculdade de Odontologia Av. Marechal Campos, 1468, Campus Maruípe, 29040-090, Vitória, ES, Brasil. Correspondência para / Correspondence to: RS PEREIRA. E-mail: <rosanadesouzapereira@yahoo.com.br>.

2 Associação Brasileira de Odontologia, Seção Vitória. Vitória, ES, Brasil

${ }^{3}$ Faculdade São Leopoldo Mandic, Curso de Odontologia, Programa de Pós-Graduação em Radiologia. Campinas, SP, Brasil.
} 


\section{INTRODUCTION}

The elimination of bacteria from root canals by mechanical instrumentation and use of irrigant solutions is normally complemented with the use of antimicrobial agents. The importance of chemical-mechanical preparation followed by the use of medication between sessions of cleaning and disinfecting root canal systems has been supported in the literature by in vitro experiments, which have demonstrated a significant reduction in the microbiota'.

Among these agents, calcium hydroxide ( $\mathrm{Ca}$ $\left.(\mathrm{OH})_{2}\right)$ is the most widely disseminated and recommended intracanal medication, because of its antimicrobial action against the majority of the bacterial species found in endodontic infections ${ }^{1}$. However, after the use of this substance, residues involved in the smear layer caused by instrumentation may remain inside the root canal. The presence of this layer may cause leakage at the interface of the canal wall and filling, and final irrigation is recommended before endodontic filling is performed in order to remove it ${ }^{2}$.

After instrumentation of the root dentin with manual instruments, a residual layer of sedimented material is formed, composed of superficial debris on the dentin walls. The smear layer has an amorphous, irregular, granular appearance, due to burnishing the components of the dentin walls during and after instrumentation ${ }^{3-4}$. In Endodontics, this layer was initially described by McComb $\&$ Smith $^{5}$ who identified the presence of not only dentin scrapings in the smear layer, but also remainders of odontoblastic processes, pulp and bacteria. Whereas, Violich \& Chandler ${ }^{4}$ pointed out that the smear layer is mainly composed of inorganic material, which prevents its effective removal with the use sodium hypochlorite. To effectuate its complete removal, some authors have suggested the use of sodium hypochlorite combined with a final irrigation with $17 \%$ EDTA $^{4,6-9}$.

Maintenance of the smear layer has been defended by some authors in the past, because they believed in the possibility that it would block the dentinal tubules and limit bacterial penetration ${ }^{10-12}$. Nevertheless, it is now known that because this layer is weakly adhered to the root canal walls, it may harbor innumerable bacteria and provide them with substrate ${ }^{12-15}$. Furthermore, when it is present on the dentinal walls and tubules, it may limit the efficacy of disinfecting the root canal system, thereby preventing the action of sodium hypochlorite used during irrigation, on the calcium hydroxide used as intracanal medication and of the endodontic cement used during filling ${ }^{4,16}$.

Removal of calcium hydroxide before filling has been a concern expressed by researchers, because of the possibility of this medication having a possible negative effect on root canal sealing ${ }^{17}$. Some theories have suggested that when calcium hydroxide comes into contact with dentin, it is capable of reducing its permeability, while others defend its incorporation into the filling cement, and thereby, of itself, providing a reduction in permeability ${ }^{18}$. Because EDTA is capable of chelating calcium ions, it has also been indicated for removing calcium hydroxide from the root canal walls, when this medication is used between sessions ${ }^{19}$.

Thus, the aim of this study was to evaluate, by means of Scanning Electron Microscopy, the efficacy of $17 \%$ Ethylenediaminetetraacetic acid (17\% EDTA) in removing the smear layer and calcium hydroxide intracanal medication in the different thirds of the root canal.

\section{METHODS}

Twenty extracted human, uniradicular, mandibular premolars were used in the study. Initially access and pulp tissue removal surgery was performed, using a No.2 diamond-coated spherical bur (KG-Sorensen, São Paulo, Brazil) at high speed, under water cooling, and then copious irrigation of the pulp chamber with $1 \%$ sodium hypochlorite and aspiration. Each root canal was explored with a type K\#10 file (Dentsply, Maillefer, Ballaigues, Switzerland), to its full extension, until the apical foramen was reached. The file was withdrawn at one millimeter from this length, thereby obtaining the real working length of each sample, the point of reference used as the parameter for this determination being the vestibular cusped of the same root.

After this, the teeth were instrumented using 32 millimeter Gates-Glidden burs in the sequence \#4, 3, 2, 1 up to 4 millimeters short of the root apex. At the working length instrumentation began with file \#15 until file \#35 was attained to conclude the apical stop, and scaling was performed with files 40, 45 and 50 .

Afterwards, the teeth were randomly divided into 4 different groups, according to the type treatment received after chemical-mechanical preparation, as follows: $\mathrm{Gl}$ - final irrigation performed with $5 \mathrm{ml}$ of $2.5 \%$ sodium hypochlorite, drying with absorbent paper points and 
sealing with zinc oxide and eugenol; Gll - irrigation with $5 \mathrm{ml}$ of $17 \%$ EDTA for 2 and a half minutes, submitted to agitation with a \#15 file, and final irrigation with $5 \mathrm{ml}$ de $2.5 \% \mathrm{NaOCl}$, drying with absorbent paper points and sealing with zinc oxide and eugenol; GIII - the teeth were irrigated with $5 \mathrm{ml}$ of $2.5 \%$ sodium hypochlorite, drying with absorbent paper points, and received application of intracanal medication with $\mathrm{Ca}(\mathrm{OH}) 2$ associated with propylenoglycol and sealed. Five days later, the sealing performed with zinc oxide and eugenol was removed and irrigation was performed with $5 \mathrm{ml}$ of $17 \%$ EDTA for 2 and a half minutes, submitted to agitation with a \#15 file, followed by final irrigation with $5 \mathrm{ml}$ de $2.5 \% \mathrm{NaOCl}$, drying with absorbent paper points and sealing with zinc oxide and eugenol; GIV - the teeth were irrigated with 5 $\mathrm{ml}$ of $17 \%$ EDTA for two and a half minutes, submitted to agitation with file \#15, followed by irrigation with $2.5 \%$ $\mathrm{NaOCl}$, drying with absorbent paper points, and afterwards the use of intracanal medication with $\mathrm{Ca}(\mathrm{OH}) 2$ associated with propylenoglycol for 5 days. Sealing performed with zinc oxide and eugenol was removed 5 days later, and irrigation was performed with $5 \mathrm{ml}$ of $17 \%$ EDTA for 2 and a half minutes, submitted to agitation with a \#15 file, followed by the use of $5 \mathrm{ml}$ of $2.5 \% \mathrm{NaOCl}$, drying with absorbent paper points and sealing with zinc oxide and eugenol.

With the use of a double faced diamond-coated disc (INTENSIV ${ }^{\circledR}$, superflex 273D, series E), at low speed (Dabi Atlanti® ${ }^{\circledR}$ Ribeirão Preto, Brazil), a guidance groove was mad on the external surface of the teeth, in the longitudinal direction of the vestibular and lingual surfaces, taking care not to attain the interior of the root canals. The absorbent paper cones were left inside the root canals to prevent the dentin dust coming from the external cut, from penetrating into the areas of root evaluation.

With the known real working length of the tooth, the length corresponding to the cervical, middle and apical thirds of the root canal was calculated, by making a transverse groove at the height of the cementenamel junction and each third of the tooth. Using a surgical hammer and stilette blade, the specimens were separated, and the crowns of the teeth were discarded. Afterwards, the six halves of the roots were separated at the longitudinal groove, and only 3 fragments were tooth were selected for evaluation.

These fragments were kept in individual flasks containing $2 \%$ buffered formol to fix them for 24 hours. The following stage of dehydration was performed with a graded series of alcohol $(70 \%, 90 \%, 95 \%, 100 \%)$ in a time interval of 15 minutes for each bath. After dehydration, the specimens were submitted to analysis by Scanning Electron Microscopy (SEM) Leica S440i with the EDS (RX) - Oxford system of analysis, which was performed in the Ultramicroscopic laboratory of the Military Institute of Engineering of the Brazilian Army ("Instituto Militar de Engenharia do Exército Brasileiro - IME") - Rio de Janeiro, Brazil. The phootomicrographs were digitized and descriptively analyzed.

\section{RESULTS}

In Group I the presence of a compact smear layer left by instrumentation was observed, particularly in the cervical and apical thirds, which was not removed by the $2.5 \% \mathrm{NaOCl}$. The obstruction of the great majority of the dentinal canals was noted, irrespective of the root canal third analyzed (Figure 1).
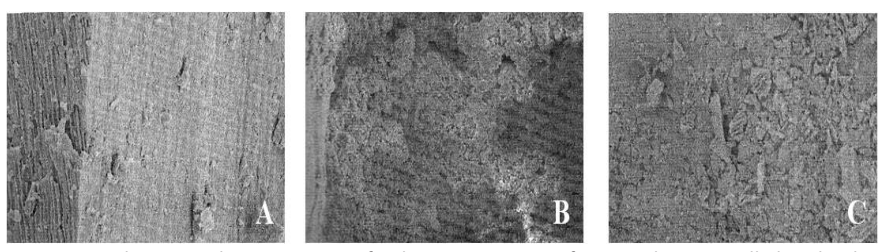

Figure 1. Showing the presence of a large quantity of smear layer in all the thirds of the canal (A - cervical, B - middle, C - apical), mainly in the cervical and apical thirds, after the final irrigation with $2.5 \%$ sodium hypochlorite (Group I).

When Group II was analyzed, the almost complete removal of the smear layer was found. In the middle third, removal of a large part of the smear layer present was observed, but in a smaller proportion or removal than that in the cervical third, whereas, in the apical third a larger number of buffered dentinal tubules and a lower degree of cleanliness of the region in comparison with the other thirds could be visualized. However, the presence of unobstructed dentinal tubules was greater in this group when compared with the other groups, in all the thirds, particularly in the cervical and middle thirds (Figure 2).
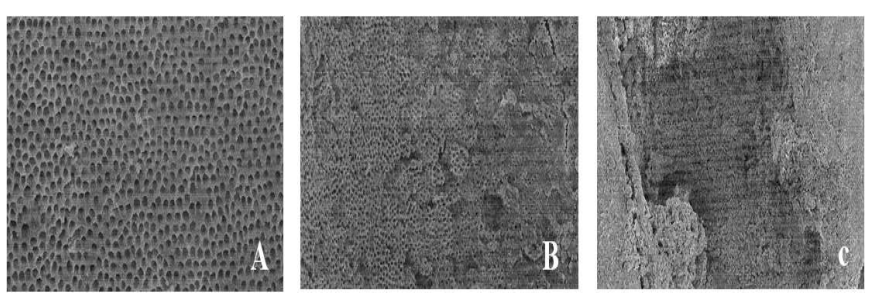

Figure 2. Showing removal of the smear layer in all the root canal thirds, in which greater removal is noted in the cervical third, followed by the middle and apical thirds (A - cervical, B - middle, C - apical) after the canals were irrigated with $17 \%$ EDTA and $2.5 \%$ sodium hypochlorite. Group II). 
In the analysis of Group III, the presence of smear layer was observed in the cervical third, and what appears to be residues of the $\mathrm{Ca}(\mathrm{OH})_{2}$ medication, which was not shown to be compacted on the canal walls; whereas at higher magnification, it was noted that in the middle third, there was a reduction in smear layer and intracanal medication residues, which are presented inside the tubules. However, in the apical third, a compacted mass of smear layer was observed (Figure 3).

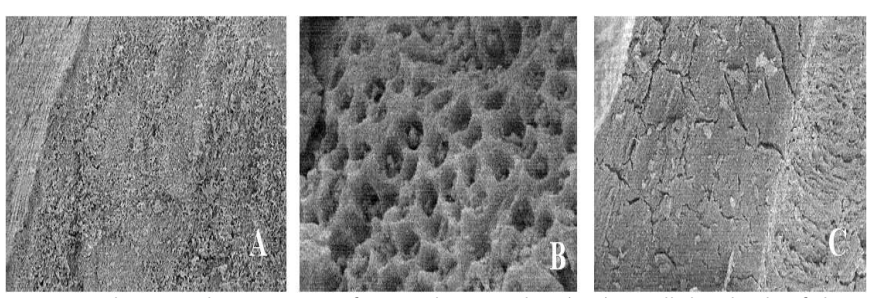

Figure 3. Showing the presence of smear layer and $\mathrm{Ca}(\mathrm{OH})_{2}$ in all the thirds of the root canal (A - cervical, B - middle, C - apical) after the use of intracanal medication, and after 5 days, the use of $17 \%$ EDTA and $2.5 \%$ sodium hypochlorite (Group III).

In Group IV in all the thirds the reduction in smear layer and $\mathrm{Ca}(\mathrm{OH})_{2}$ medication and presence of various unobstructed dentinal tubules was evident, and consequently, cleaner root canal walls in the cervical and middle thirds. However, in the apical third this cleanliness was not so evident. One also notes that residues with a rounded shape and lighter color were observed in the cervical and middle thirds of the root canal, differently from the images observed in Group II, which may be indicated as being residues of $\mathrm{Ca}(\mathrm{OH})_{2}$ (Figure 4). When compared with Group II, which presented the bests results, it was evident that the 17\% EDTA was effective in removing both smear layer and residues of the $\mathrm{Ca}(\mathrm{OH})_{2}$ - based medication.

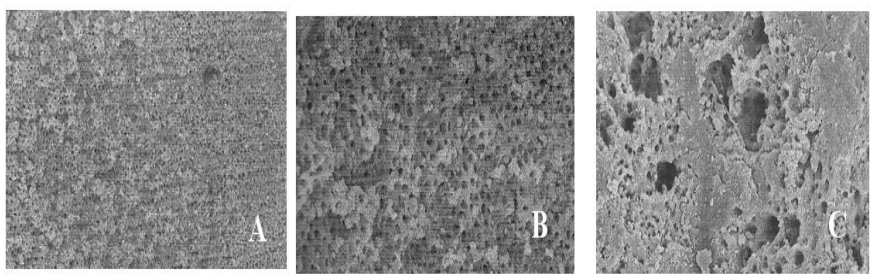

Figure 4. Showing the presence of smear layer and $\mathrm{Ca}(\mathrm{OH}) 2$ in all the thirds of the root canal (A - cervical, B - middle, C - apical) after the use of intracanal medication, and after 5 days, the use of $17 \%$ EDTA and $2.5 \%$ sodium hypochlorite (Group IV).

\section{DISCUSSION}

There is a great deal of controversy about the advantages and disadvantages of maintaining or removing the smear layer from the root canal walls. Although it continues to be a polemic subject, there is a trend in the literature towards the indication of removing the smear layer and the possible residues left by calcium hydroxide, considering this a beneficial procedure for attaining hermetic sealing of the entire root canal system ${ }^{4,16,18}$.

The effectiveness of sodium hypochlorite in dissolving organic tissues is well known. However, its capacity to remove the smear layer from the instrumented root canals was considered insufficient. The use of hypochlorite during or after the instrumentation procedures promotes superficial cleaning of the root canal in permanent teeth, when the smear layer is present. However, the EDTA solution and its associations are routinely used for this purpose, because of its satisfactory chelating property $4,6-9,19$.

Some authors have pointed out that when $\mathrm{Ca}(\mathrm{OH})_{2}$ is used as intracanal medication, it should be completely removed from the root canal walls with the use of EDTA, followed by $\mathrm{NaOCl}$, to enable effective sealing of the root canal and penetration of the cement into the root canal system. In comparative studies, authors have concluded that even with the use of these solutions it was not possible to completely remove $\mathrm{Ca}(\mathrm{OH})_{2}$ from the canal ${ }^{18-19}$.

When analyzing the photomicrographs of Group 1 , it could be observed that the use of hypochlorite solution alone was not capable of removing the smear layer from the root canal walls, and this may be explained by the fact that the smear layer is composed of both organic and inorganic products, which makes it necessary to use a solution to complement the action of hypochlorite, which acts only on the organic portion of this layer. A fact proved by Group II, in which an almost total number of open dentinal tubules in the cervical third, and a large number in the middle third were observed, as a result of the use of $17 \%$ EDTA associated with hypochlorite. These findings are in agreement with those of White et al. ${ }^{6}$ and Violich \& Chandler ${ }^{4}$.

In Group III, a difference was verified between the smear layer remaining in this group, and that observed in Group I, the latter being more compact. The difference between the treatment of Group I and that of Group III was the use of $17 \%$ EDTA after the $\mathrm{Ca}(\mathrm{OH})_{2}$ medication dressing to prepare the root canal for filling. It was noted that the use of the $\mathrm{Ca}(\mathrm{OH})_{2}$ - based intracanal medication made it difficult to remove the smear layer with the use of $17 \%$ EDTA $17 \%$ associated with hypochlorite, which may be observed when comparing the photomicrographs of Group II with those of Group III. Nevertheless, the use of the chelating solution (EDTA) after the use of $\mathrm{Ca}(\mathrm{OH})_{2}$ resulted in a higher level of smear layer removal than that achieved when EDTA was not used, as was the case in Group I. 
However, when the chelating solution was used before the medication dressing and after it, little difference was noted in the results observed when Group II was compared with Group IV. With regard thereto, one may consider that $\mathrm{Ca}(\mathrm{OH})_{2}$, appears to present a lower degree of fixation on the dentinal walls than the smear layer, in agreement with the results of Miranda ${ }^{20}$. These results indicate a possible effectiveness of EDTA in removing $\mathrm{Ca}(\mathrm{OH})_{2}$, residues, in addition to its proven effectiveness on the smear layer. Therefore, the use of the $\mathrm{Ca}(\mathrm{OH})_{2}{ }^{-}$ based medication dressing is justified, provided that it is performed in the manner in which it was done in Group $\mathrm{IV}$, in order to take advantage of the benefits of this medication, without the inconvenience of obstructing the dentinal tubules and root canal system.

With regard to the cleanliness achieved in the different areas of the root canal, it may be pointed out that the cervical and middle thirds were those that presented greater capacity to be cleaned. This may be explained as being due to the irrigation system having attained the apical third less efficiently, as a result of the size of the aspiration needle and cannula not reaching the complete extension of the working length of the root canal, thus not allowing the irrigant solutions to achieve the desired result. These limitations have also been pointed out by Pereira ${ }^{21}$.

\section{CONCLUSION}

According to the methodology used and the results obtained, it could be concluded that the use of $17 \%$ EDTA favored the removal of the smear layer and $\mathrm{Ca}(\mathrm{OH})_{2}-$ based intracanal medication residues, in all the root canal thirds, thus justifying the use of these medications with the purpose of taking advantage of their benefits, without the inconvenience of obstructing the dentinal tubules and root canal systems.

\section{Collaborators}

RS PEREIRA supervised the research and participated in writing the paper. GS PEREIRA was responsible for preparing teeth for SEM, SEM and monitoring the technical wording of article. JM BARROSO co-supervised the research and participated in writing the paper. CHS BARROS was responsible for opening the teeth and instrumentation of root canals and writing of the article. MGLB BORTOLOTTI was responsible for the evaluation of SEM in the different thirds of root canals and writing of the article. JLC JUNQUEIRA revised the text and in the drafting of the article.

\section{REFERENCES}

1. Bystrom A, Claesson R, Sundqvist $G$. The antibacterial effect of camphorated paramonochlorophenol, camphorated phenol and calcium hydroxide in the treatment of infected root canals. Endod Dent Traumatol. 1985;1(5):170-5. doi: 10.1111/j.16009657.1985.tb00652.x.

2. Lui JN, Kuah HG, Chen NN. Effect of EDTA with and without surfactants or ultrasonics on removal of smear layer. J Endod. 2007;33(4):472-5. doi: 10.1016/j.joen.2006.12.007.

3. Daghustani M, Alhammadi A, Merdad K, Ohlin J, Erhardt F, Ahlquist M. Comparison between high concentration EDTA $(24 \%)$ and low concentration EDTA (3\%) with surfactant upon removal of smear layer after rotary instrumentation: a SEM study. Swed Dent J. 2011;35(1):9-15.

4. Violich DR., Chandler NP. The smear layer in endodontics: a review. Int Endod J. 2010;43:2-15. doi:10.1111/j.13652591.2009.01627.x.

5. McComb D, Smith DC. A preliminary scanning electron microscopic study of root canals after endodontic procedures. J Endod. 1975;1(7):238-42. doi: 10.1016/S0099-2399(75).

6. White RR, Goldman M, Lins PS. The influence of the smear layer upon dentinal tubule penetration by plastic filling materials. J Endod. 1987;13(8)369-74.

7. Baumggartner JC, Mader CL. A scanning electron microscope evaluation of four root canal irrigation regimens. J Endod. 1987;13(4):147-57. doi: 10.1016/S0099-2399(87)80132-2.

8. Câmara AC, Albuquerque MM, Aguiar CM. Soluções irrigadoras utilizadas para o preparo biomecânico de canais radiculares. Pesq Bras Odontoped Clin Integr. 2010;10(1):127-33. doi: 10.4 034/1519.0501.2010.0101.0021.

9. Khedmat S, Shokouhinejad N. Comparison of the efficacy of three chelating agents in smear layer removal. J Endod. 2008;34(5):599-602. doi: 10.1016/j.joen.2008.02.023.

10. Michelich VJ, Schuster GS, Pashley DH. Bacterial penetration of human dentin in vitro. J Dent Res. 1980;59(8):1398-403. doi: 10.1177/00220345800590080701.

11. Pashley DH, Michelich $V$, Kehl T. Dentin permeability: effects of smear layer removal. J Prosthet Dent. 1981;46(5):531-7.

12. Dechichi P, Moura CCG. Smear layer: a brief review of general concepts. Part I. Characteristics, compounds, structure, bacteria and sealing. RFO UPE. 2006;11(2)96-99. 
13. Mader CL, Baumgartner JC, Peters DD. Scanning electron microscopic investigation of the smeared layer on root canal walls. J Endod. 1984;10(10):477-83. doi: 10.1016/S00992399(84)80204-6.

14. Cameron JA. The synergistic relationship between ultrasound and sodium hypochlorite: a scanning electron microscope evaluation. J Endod. 1987;13(11):541-5. doi: 10.1016/S00992399(87)80034-1.

15. Meryon SD, Brook AM. Penetration of dentine by three oral bacteria in vitro and their associated cytotoxicity. Int Endod J. 1990;23(4):196-202. doi: 10.1111/j.1365-2591.1990. tb00100.x

16. Torabinejad M, Handysides R, Khademi AA, Bakland LK. Clinical implications of the smear layer in endodontics: a review. Oral Surg Oral Med Oral Pathol Oral Radiol Endod. 2002;94(6):65866. doi: 10.1067/moe.2002.128962.

17. Holland R, Alexandre AC, Murata SS, dos Santos CA, Dezan Júnior E. Apical leakage Following root canal dressing with calcium hydroxide. Endod Dent Traumatol. 1995;11(6):261-9.

18. Calt S, Serper A. Dentinal tubule penetration of root canal sealers after root canal dressing with calcium hydroxide. J Endod. 1999;25(6):431-3. doi: 10.1016/S0099-2399(99)80273-8.
19. Moraes IG, Nunes E, Berbert A, Duarte MAH, Betti LV. Influência do hidróxido de cálcio e do EDTA na marcação da infiltração marginal de azul de metileno em obturação de canais radiculares. Rev Fac Odontol Bauru. 2000;8(12):37-44.

20. Miranda PF. Influência da medicação curativa intracanal $\left(\mathrm{Ca}(\mathrm{OH})_{2}\right)$ sobre a obturação do sistema de canais radiculares [monografia]. Vitória: Associação Brasileira de Odontologia; 2004.

21. Pereira ESJ. Avaliação da limpeza da superfície dentinária de canais radiculares de molares após utilização de diferentes sistemas de irrigação [dissertação]. Belo Horizonte: Universidade Federal de Minas Gerais; 2009.
Received on: 6/10/2012

Final version resubmitted on: 27/6/2013

Approved on: 5/11/2013 